\title{
Hücresel İmalat Sistemlerinin K-Means Algoritması ve Genetik Algoritma İle Tasarlanması: Bir Uygulama
}

\author{
${ }^{*}$ Serap Ercan Cömert, ${ }^{1}$ Seda Hatice Gökler, ${ }^{1}$ Harun Reşit Yazgan \\ ${ }^{1}$ Sakarya Üniversitesi, Mühendislik Fakültesi, Endüstri Mühendisliği
}

Geliş Tarihi: 2016-09-23 Kabul Tarihi: 2016-10-10

\section{$\ddot{O ̈ z}$}

Günümüzde, işletmeler üretimdeki kayıpları azaltmak ve verimliliklerini arttırmak amacıyla atölye tipi yerleşimden hücresel yapıya geçişe büyük önem vermektedirler. Hücresel imalata geçişteki en önemli aşamalardan birisi de kümeleme işlemidir. Sonrasında ise, kümeleme sonuçları dikkate alınır ve en uygun hücre yapıları tasarlanarak üretimdeki gereksiz taşımaların azaltılması ile üretim miktarının artırılması, nihayetinde ise sistem verimliğinin artırılması hedeflenmektedir.

Bu çalışmada atölye tipi yerleşime sahip bir imalat işletmesi ele alınarak öncelikli olarak üretimi devam eden ürünlerin üretildiği makinalara K-means algoritması ve genetik algoritma uygulanarak uygun kümeler oluşturulmuştur. Çalışmanın sonucunda ise, mevcut ve önerilen iki algoritmanın elde ettiği toplam taşıma maliyetleri karşılaştırılmış ve önerilen sistemin sağladığı üstünlükler bir örnek uygulama üzerinde gösterilmiştir.

Anahtar Sözcükler: Kümeleme Analizi, K-means algoritması, Genetik Algoritma

\section{Design of Cellular Manufacturing Systems Using Genetic Algorithm and K- means Algorithm: An Application}

\author{
${ }^{*}$ Serap Ercan Cömert, ${ }^{1}$ Seda Hatice Gökler, ${ }^{1}$ Harun Reşit Yazgan \\ ${ }^{1}$ Sakarya University, Faculty of Engineering, Industrial Engineering
}

Received Date: 2016-09-23 Accepted Date: 2016-10-10

\begin{abstract}
Today, businesses pay attention to transfer from a workshop to a cellular layout to reduce losses in production and increase their efficiency. In the transition processes, one of the most important stage for a cellular manufacturing is a clustering process. Afterwards, clustering results are considered and aimed to reduce unnecessary transport, increase the production volume of the production and increase ultimately a system efficiency.

In this study, transferring a manufacturing company based on a workshop layout was discussed. Then, two algorithms such as K-means and genetic were applied to continuous production of products and appropriate clusters were formed. At the end of the study, current and proposed two algorithms' total transport costs were compared, and advantages of the proposed system is illustrated based on a case study.
\end{abstract}

Keywords: Clustering Analysis, K-means Algorithm, Genetic Algorithm

1.Giriş

İşletmeler rekabet şartlarına ayak uydurabilmek için kaliteli ürünler üretme ve ürün çeşitlendirmede fonksiyonel olmak zorundadırlar. Bunları gerçekleştirebilmek içinde maliyetlerini düşürmeye yönelik çalışmalar yapmaları gerekmektedir [1]. Bu çalışmaların olmazsa olmazlarından biride hücresel üretimdir [2].
Benzer özellikler taşıyan parçalar bir araya toplanarak hücreleri oluşturmakta, hücre içerisinde ise benzer parçaların üretilebilmesi amacıyla makinelerin bir araya getirilmesi hücresel imalat olarak adlandırılmaktadır [3]. Hücresel imalatın en önemli aşaması ise kümelerin oluşturulmasıdır. Kümeleme analizinin amacı; verileri değişkenler arasındaki benzerlik veya farklılıklara göre eş gruplara bölmektir [4]. 
Bu çalışmada alüminyum ve paslanmaz çelikten 200 çeşit profil, aksesuar ve komponent üretimi gerçekleştiren bir imalat işletmesindeki üretilmekte olan ürünlerde k-means algoritması ve genetik algoritma ile parça kümeleri oluşturulmuştur. Daha sonra oluşturulan hücrelere göre işletmenin yerleşimi düzenlenmiş ve toplam taşıma maliyetleri hesaplanmıştır. Son olarak ise mevcut sistem ile geliştirilen hücresel sistemler karşılaştırılmıştır.

\section{Hücresel İmalat}

Hücresel imalat; işletmede üretilen parçaların bulunduğu hücre ile en çok, diğer hücrelerle en az ilişki ile işlendiği duruma göre gruplandırılmasıdır. Hücresel imalatta parça ailelerinin ve makine gruplarının eşleştirilmesi söz konusudur.

Hücresel imalat sistemleri oluşturulurken amaç; üretim maliyetini, işlem süresini ve/veya alan kaybını azaltmaktır. Amaç fonksiyonunun belirlenmesinden sonra sirayı makineler aras1 uzaklık matrisi ve parça - makine akış matrisinin oluşturulması almaktadır. Özetle hücresel imalat sisteminin kurulabilmesi için toplam hücre sayısı, bir hücredeki makine sayısı ve bir makine başına düşen parça sayısına ihtiyaç duyulmaktadır [5].

Çalışmada hücresel imalata geçebilmek için kümeleme analizi uygulanmıştır.

Kümeleme analizi kavramı ilk kez Tryon tarafından 1939 tarihinde literatüre kazandırılmıştır [6]. Kümeleme analizi, nesneleri birbirlerine benzerliklerine göre sinıflandırmaya yarayan bir tekniktir. Bu teknikte nesnelere önceden belirlenen kriterlere göre kümelendiğinde aynı kümedeki nesnelerin özellikleri birbirine çok benzerken kümeler arası ölçülen özellikler ise birbirine benzememektedir [7]. Kümeleme analizinin genel amacı, gruplanmamış verileri benzerliklerine göre gruplandırarak araştırmacıya özetleyici bilgiler sunmaktır. Kümeleme tekniğinin genel yapısı ve kullanılan yöntemler Şekil 1'de gösterilmektedir [8].

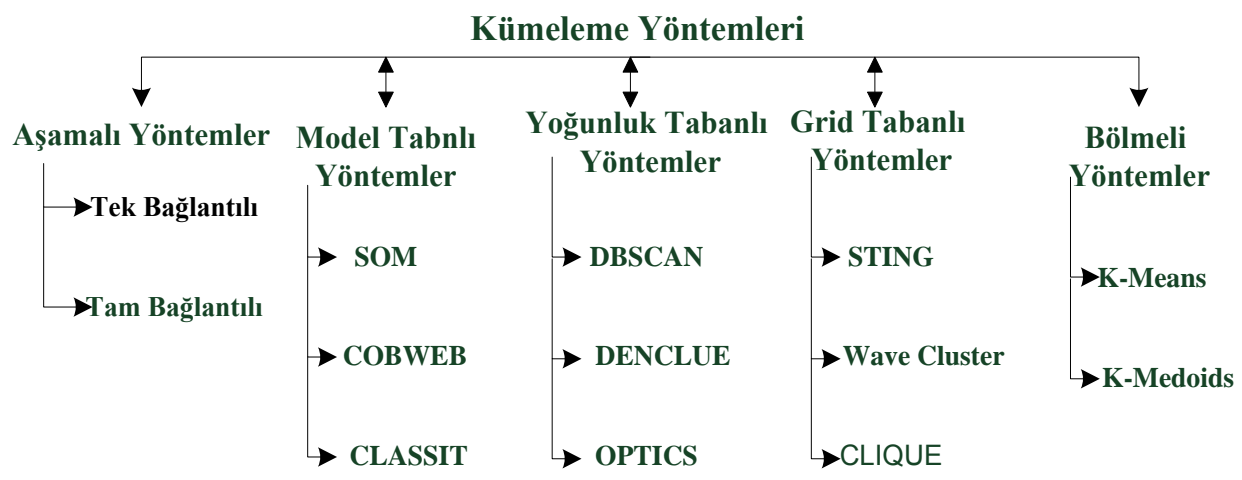

Şekil 1. Kümeleme tekniğinin genel yapısı ve kullanılan yöntemler

\section{3. Çalışmada Kullanılan Metotlar}

Çalışmada kümeleme yöntemlerinden K-means kümeleme algoritması ve sezgisel yöntemlerden genetik algoritma kullanılmıştır. K-means kümeleme algoritmasının ve genetik algoritmanın seçilmesinin sebebi denemelerimiz sonucunda ele aldığımız probleme en uygun algoritmalar olduğu kanaatine vardığımızdandır.

\subsection{K-Means Kümeleme Algoritmast}

K-means 1967 yılında J.B. MacQueen tarafindan geliştirilen en eski kümeleme algoritmalarından biridir [9].

K-means kümeleme algoritmasının performansının değerlendirilmesinde en yaygın olarak karesel hata kriteri (SSE) kullanılır. En düşük SSE değerine sahip kümelemenin en iyi sonucu verdiği kabul edilir.
Formül 1'de nesnelerin ait oldukları kümenin merkez noktasına olan uzaklıklarının karelerinin toplamının hesabı gösterilmektedir. Burada; K küme sayısını, $\mathrm{m}_{\mathrm{i}}$ kümenin merkez noktasını ve x kümede bulunan nesneyi göstermektedir [10].

$\mathrm{SSE}=\sum_{i=1}^{K} \sum_{X \in C i} U z \operatorname{aklik}^{2}(m i, x)$

K-means algoritmasının temeli, verilerin çeşitli özelliklere sahip k tane nesneye bölünmesi esasına dayanır [11]. K tane nesneden biri temsilci nesne olarak seçilir. Bir kümedeki diğer nesnelere olan ortalama uzaklığın ortalamasını en aza indiren kümenin merkezi nesnesine temsilci nesne denir. Bu nedenle, bu kümeleme tekniği her bir nesne ve onun referans noktasi arasındaki benzersizliklerin toplamını en aza indirme mantığını esas alarak uygulanmaktadır [12]. 


\subsection{Genetik Algoritma}

Genetik algoritma (GA) doğadaki evrim süreçlerinden esinlenerek geliştirilen bir algoritmadır. 1975 yılında, Michigan üniversitesinde bulunan John Holland yeni çocuklar oluşturmak için ebeveynlerden gelen bilgileri farklı kombinasyonlara göre birleştirip genetik algoritma tekniğini bulmuştur. Özetle, genetik algoritma (GA) rastgele arama teknikleri ile çözüme ulaşmaya çalışan ve parametre kodlama esasına dayanan sezgisel bir tekniktir [13]. GA, kesin çözüm yöntemleri ile çözülmesi imkânsız olan NP-hard problemler olarak adlandırlan problemlerin çözümüne imkân sağlamaktadır [14].

Genetik algoritmayı anlayabilmek için öncelikle bazı kavramlar açıklanmalıdır. Genetik algoritmada çözüme ait genetik bilgi taşıyan her bir elemana gen adı verilmektedir. Bir veya daha fazla gen bir araya gelerek problemin çözümüne ait tüm bilgiyi içeren dizileri oluştururlar. $\mathrm{Bu}$ diziler kromozom olarak adlandırılmaktadır. Her bir kromozom bir çözümü temsil etmektedir. Kromozomlar bir araya gelerek ise popülasyonları oluşturmaktadır. Genetik algoritmada kromozomların başarısını değerlendirmek için uygunluk değeri olarak adlandırılan bir kavram kullanılmaktadır. Genetik algoritma çalışmalarının ilk aşamasında yapılması gereken işlem genleri kodlama işlemidir. Genetik algoritmalarda bağımsız parametreler kendileri yerine onları temsil eden serileri kullanılmasına kodlama denilmektedir.

Ele alınan problemin çözümündeki ilk aşama kromozom yapısıdır. Bu nedenle çözüm uzayı doğru tahmin edilmelidir. Kromozomlar makineleri, işlemleri ve parçaları eksiksiz olarak içermelidir. Gen sayısı; makine/işlem sayısı ve parça sayısının toplamı, hücre numarasını oluşturmalıdır [15].

Genetik algoritmalarda diğer önemli nokta ise operatörlerdir. Operatörler uygulamalara göre farklılık göstermektedir. Yaygın olarak kullanılan operatörler; yeniden üretim operatörü, çaprazlama operatörü ve mutasyon operatörüdür.

- Yeniden üretim operatörü: Genetik algoritma ile problem çözülmeye karar verildiğinde öncelikle yapılacak işlem başlangıç popülasyonunun oluşturulmasına nesil üretimi; başlangıç popülasyonu oluşturulduktan sonra algoritmanın işleyişini sağlamak için yeni bireyler oluşturulmasına da kararlı durum üretimi denir. En bilinenleri rulet seçimi yöntemi ve turnuva seçim yöntemidir.
- Çaprazlama operatörü: İki dizinin bir araya gelerek karşılıklı gen yapılarının değişimi ile yeni dizilerin oluşumunu sağlayan operatördür. Örnek olarak tek noktalı çaprazlama, iki noktalı çaprazlama ve uniform çaprazlama verilebilir.

- Mutasyon operatörü: Mevcut kromozomlardan yeni kromozomlar üretme yeteneğine sahip operatörlere mutasyon operatörleri denir. Döndürme mutasyon operatörü ve değiş-tokuş operatörü örnek olarak verilebilir. Genetik algoritmaların genel akış şeması Şekil 2'de gösterilmiştir.

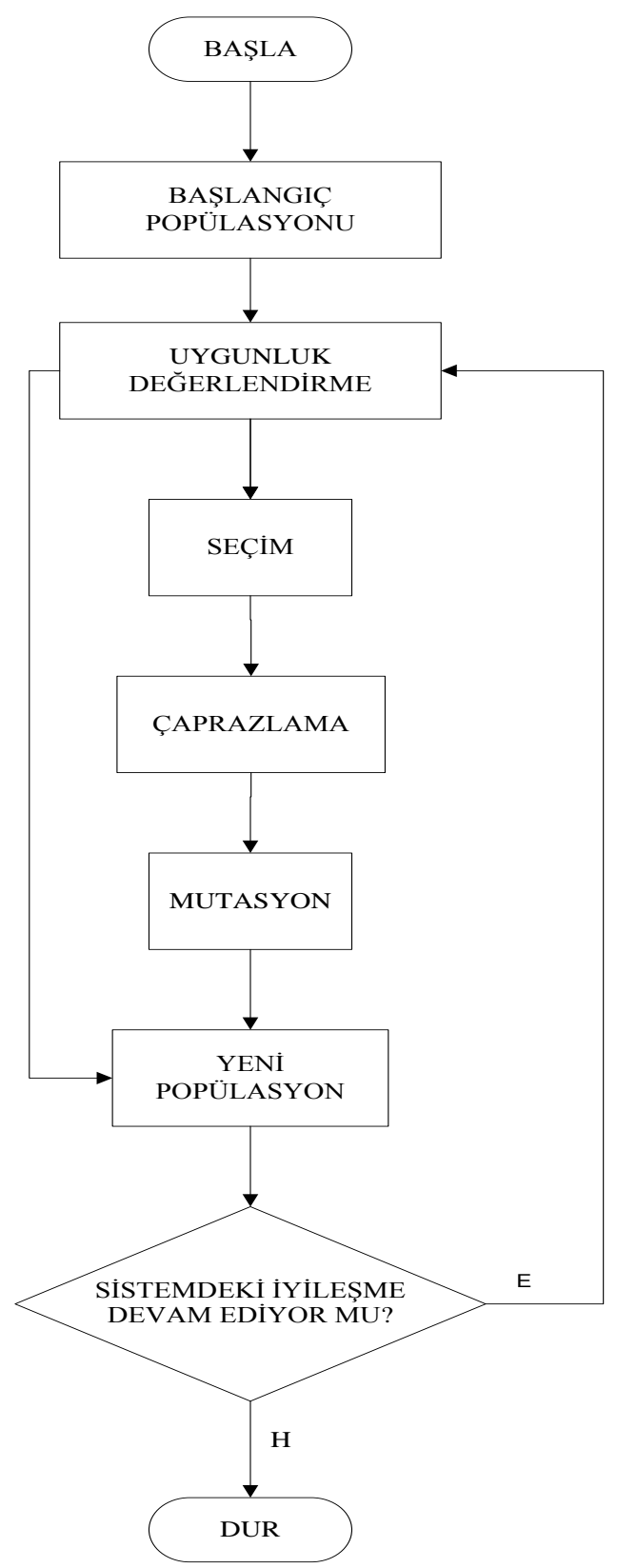

Şekil 2. Genetik Algoritmaların Genel Akış Şeması 


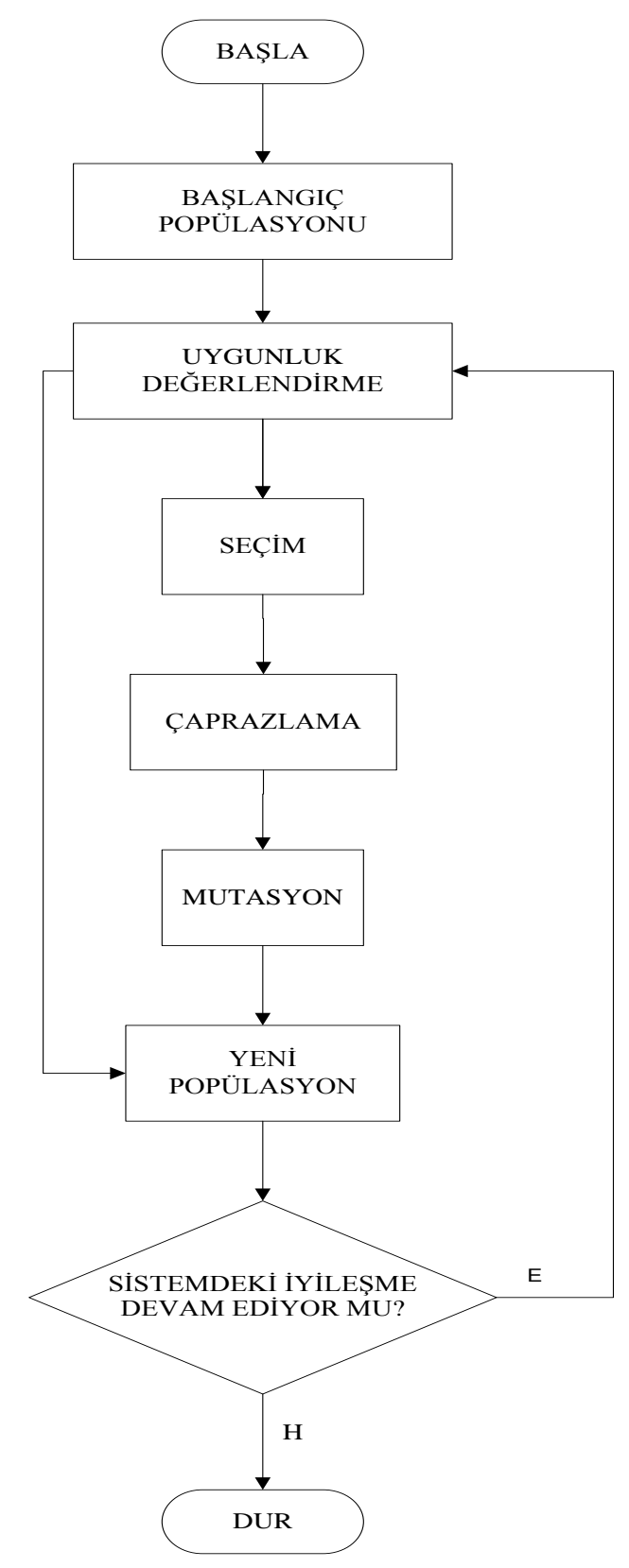

Şekil 2. Genetik Algoritmaların Genel Akış Şeması

Genetik algoritmanın adımları ise kısaca şu şekildedir; genetik algoritma, ele alınan problemin verilerine dayanarak başlangıç popülasyonunun oluşturulması ile başlar. Daha sonra, iterasyon sayısı ve durdurma kriteri belirlenir, bireylerin uyum değeri hesaplanır ve uygum değerine göre bireylerin eşleştirilmesi sağlanır [16]. Eşlenen bireyler arasında çaprazlama işlemi ile çeşitlilik sağlanır. Çaprazlama işleminden sonra mutasyon oranına göre bazı bireyler mutasyona uğrar. Oluşan yeni bireylerin kromozomları gerçek kromozom içeriği ile karşllaştırılır. Oluşan her yeni bireylerin uyum değerleri hesaplanır ve uygunluk değeri yüksek olan bireyler ebeveynlerle yer değiştirerek uygunluk popülasyonunu oluştururlar [17].
Son olarak; sabit bir iterasyon sayısı veya çözüm süresine erişildiğinde zaman, belirli bir iterasyon süresince hiçbir iyileşme gözlenmediği zaman genetik algoritma durdurulur.

Çalışmada da hücresel imalatın amacı doğrultusunda genetik algoritma için amaç fonksiyonu yazılıp, kromozom uygunlukları bu amacın doğrulanmasına göre belirlenmiştir.

\section{Uygulama}

$\mathrm{Bu}$ çalışmada bir imalat işletmesinde k-means kümeleme algoritması ve genetik algoritma ile makine ve parça gruplarından hücreler oluşturulup geleneksel üretimden hücresel üretime geçiş yapılmıştır. Önerilen sistemler ile mevcut sistem birbirleriyle karşılaştırılarak üstünlükleri gösterilmiştir.

Uygulama; alüminyum ve paslanmaz çelikten 200 çeşit profil, aksesuar ve komponent üretimi yapılan bir fabrikada gerçekleştirilmiştir. İşletme, hizmet vermeye başladığında atölye denilecek küçük bir işletme iken daha sonra yeni makinelerin alınmasıyla $16.000 \mathrm{~m}^{2}$ lik alana yayılmış bir fabrika halini almıştır. İşletmeye büyüme evresinde eklenen makineler gelişi güzel olarak yerleştirilmiş ancak ilerleyen zamanlarda 9 çeşit makine alınmasıyla ürün taşıma maliyetinin çok fazla olduğu görülmüss, kümeleme analizi yapılarak aynı işlemleri gören ürünler bir araya getirilip taşıma süreleri dolayısıyla taşıma maliyetleri azaltılmaya çalışılmıştır. Kümeleme analizi sonucunda hücreler oluşturulurken sabit kalması gereken eloksal makinesinin yeri değiştirilmemiştir.

Çalışmada öncelikle ticari bir yazılım kullanılarak "K-Means Algoritması" ile 200 çeşit ürün işlem gördüğü tezgâhlara atanmış ve 3 adet hücre oluşumunun denemelerimiz sonucunda en ideal çözümü vereceği görülmüştür. Oluşan küme atamasına ait bilgiler Tablo 1'de görülmektedir.

Tablo 1. K-means algoritması sonucu oluşan küme ataması

\begin{tabular}{lcc}
\hline MAKİNE & Numarası & $\begin{array}{c}\text { ATANDIĞI } \\
\text { KÜME }\end{array}$ \\
\hline Boy Kesme & 1 & 1 \\
Sap İşleme & 2 & 1 \\
CNC & 3 & 1 \\
Kimyasal & 4 & 2 \\
Yüzey İşleme & 5 & 2 \\
Pres & 6 & 2 \\
Polisaj & 7 & 2 \\
Eloksal & 8 & 3 \\
Boya & 9 & 3 \\
Montaj & & \\
\hline
\end{tabular}


Program sonucuna göre boy kesme, sap işleme ve CNC makinelerinden geçen ürünler 1.kümeye; kimyasal yüzey işleme, pres, polisaj ve eloksal makinelerinden geçen ürünler 2.kümeye; boya ve montaj işlemlerinden geçen ürünler 3.kümeye atanmıştır.

Daha sonra MATLAB toolbox'ı kullanılarak genetik algoritma ile ikinci bir kümeleme çalışması yapılmış ve 3 kümeye ayrılmıştır. Oluşan küme atamasına ait bilgiler Tablo 2'de görülmektedir. Genetik algoritmanın sonucuna göre boy kesme, $\mathrm{CNC}$ ve sap işleme makinelerinden geçen ürünler 1.kümeye; pres, polisaj ve kimyasal yüzey işleme makinelerinden geçen ürünler 2.kümeye; eloksal, boya ve montaj işlemlerinden geçen ürünler 3.kümeye atanmıştır. WinQSB programı yardımıyla tesis yerleştirme problemi çözülerek mevcut sistem ile önerilen sistemlerin taşıma maliyetleri karşılaştırılmıştır. Bunun için işletmeden mevcut yerleşim düzenine ait koordinatlar alınmış, makineler arasında taşıma yapılan aylık talep miktarları kullanılmış ve Şekil 3 'te gösterilmiştir.

Tablo 2. Genetik algoritma sonucu oluşan küme atamas1

\begin{tabular}{lcc}
\hline MAKİNE & Numara & $\begin{array}{c}\text { ATANDIĞI } \\
\text { KÜME }\end{array}$ \\
\hline Boy Kesme & 1 & 1 \\
CNC & 2 & 1 \\
Sap İşleme & 3 & 1 \\
Pres & 4 & 2 \\
Polisaj & 5 & 2 \\
Kimyasal Yüzey & 6 & 2 \\
İşleme & 7 & 3 \\
Eloksal & 8 & 3 \\
Boya & 9 & 3 \\
Montaj & &
\end{tabular}

WinQSB programın çalıştırılması sonucunda mevcut yerleşim planı ve taşıma maliyeti Şekil 4'teki gibi bulunmuştur.

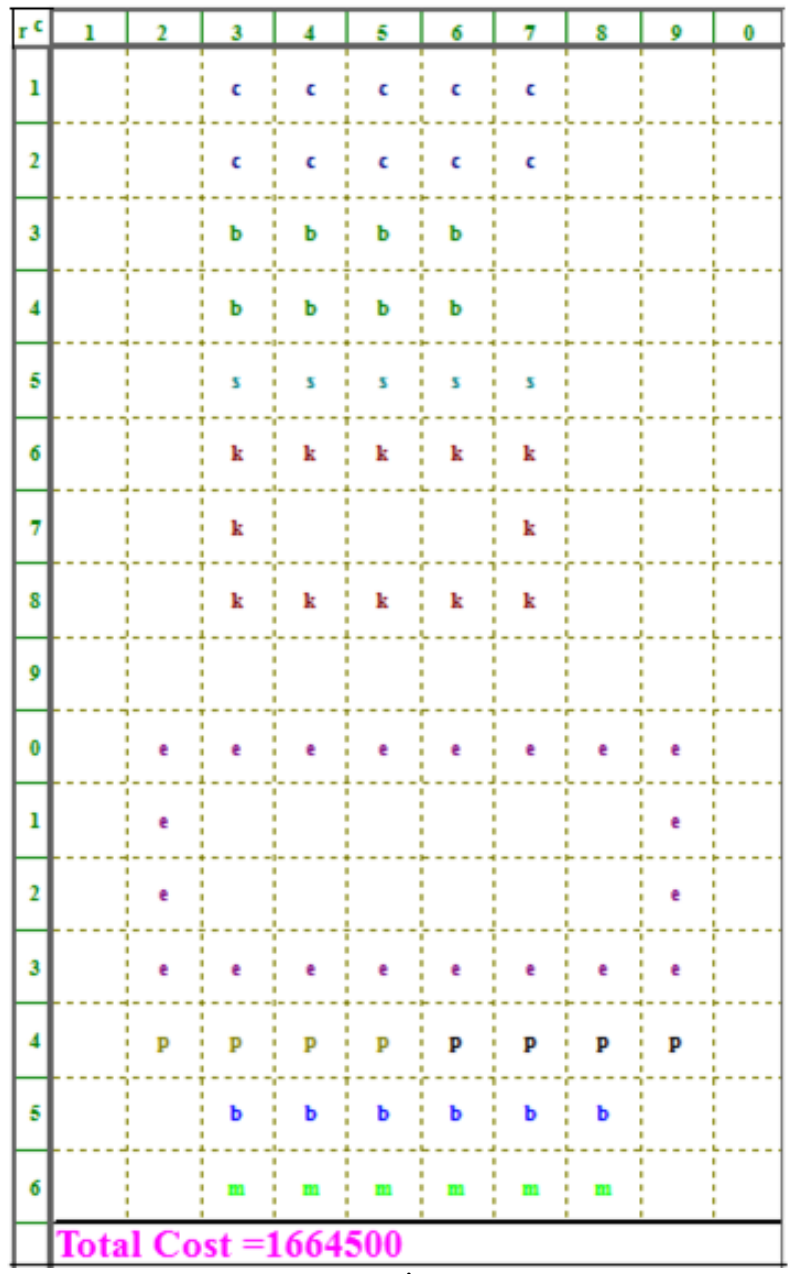

c:CNC, b:Boy Kesme, s:Sap İşleme, k: Kimyasal Yüzey İşleme, e: Eloksal, p: Pres, p: Polisaj, b: Boya, m:Montaj Şekil 4. Mevcut sisteme ait taşıma maliyeti

\begin{tabular}{|c|c|c|c|c|c|c|c|c|c|c|c|c|}
\hline $\begin{array}{c}\text { Department } \\
\text { Number }\end{array}$ & $\begin{array}{c}\text { Department } \\
\text { Name }\end{array}$ & $\begin{array}{c}\text { Location } \\
\text { Fixed }\end{array}$ & $\begin{array}{c}\text { To Dep. } 1 \\
\text { Flow/Unit Cost }\end{array}$ & $\begin{array}{c}\text { To Dep. } 2 \\
\text { Flow/Unit Cost }\end{array}$ & $\begin{array}{c}\text { To Dep. } 3 \\
\text { Flow/Unit Cost }\end{array}$ & $\begin{array}{c}\text { To Dep. } 4 \\
\text { Flow/Unit Cost }\end{array}$ & $\begin{array}{c}\text { To Dep. } 5 \\
\text { Flow/Unit Cost }\end{array}$ & $\begin{array}{c}\text { To Dep. } 6 \\
\text { Flow/Unit Cost }\end{array}$ & $\begin{array}{c}\text { To Dep. } 7 \\
\text { Flow/Unit Cost }\end{array}$ & $\begin{array}{c}\text { To Dep. } 8 \\
\text { Flow/Unit Cost } \\
\end{array}$ & $\begin{array}{c}\text { To Dep. } 9 \\
\text { Flow/Unit Cost }\end{array}$ & $\begin{array}{c}\text { Initial Layout in } \\
\text { Cell Locations }[\text { e.g. }(3,5),(1,1)-(2,4)]\end{array}$ \\
\hline 1 & Cnc & No & & & 56000 & & & & & & & $(1,3)-(2,7)$ \\
\hline 2 & boykesme & No & 56000 & & & & & & & & & $(3,3)-(4,6)$ \\
\hline 3 & sapisleme & No & & & & & & 35000 & & & & $(5,3)-(5,7)$ \\
\hline 4 & kimyasalyi & No & & & & & 40000 & & & & & $(6,3)-(8,7)$ \\
\hline 5 & eloksal & Yes & & & & & & & & 56000 & & $(10,2)-(13,9)$ \\
\hline 6 & pres & No & & & & & & & 56000 & & & $(14,2)-(14,5]$ \\
\hline 7 & polisaj & No & & & & 30000 & & & & & & $(14,6)-(14,9)$ \\
\hline 8 & boya & No & & & & & & & & & 56000 & $(15,3)-(15,8)$ \\
\hline 9 & montaj & No & & & & & & & & & & $(16,3)-(16,8)$ \\
\hline
\end{tabular}

Şekil 3. Mevcut yerleşim düzenine ait koordinatlar ve aylık talep miktarları

Daha sonra aynı işlemler k-means algoritması ve genetik algoritma ile kümeleme yapıldıktan sonra elde edilen taşıma maliyetlerini bulmak için yapılmıştır. Aralarında taşıma yapılan makinelerin koordinatları ve aylık taşınan talep miktarları k- means algoritması için Şekil 5'te genetik algoritma için ise Şekil 6'da verilmiştir. K-means algoritması ve genetik algoritma ile oluşturulan yeni yerleşim düzenleri ve taşıma maliyetleri sırasıyla Şekil 7'de gösterilmiştir. 


\begin{tabular}{|c|c|c|c|c|c|c|c|c|c|c|c|c|}
\hline $\begin{array}{l}\text { Department } \\
\text { Number }\end{array}$ & $\begin{array}{l}\text { Department } \\
\text { Name }\end{array}$ & $\begin{array}{l}\text { Location } \\
\text { Fixed }\end{array}$ & $\begin{array}{c}\text { To Dep. } 1 \\
\text { Flow/Unit Cost }\end{array}$ & $\begin{array}{c}\text { To Dep. } 2 \\
\text { Flow/Unit Cost }\end{array}$ & $\begin{array}{c}\text { To Dep. } 3 \\
\text { Flow/Unit Cost }\end{array}$ & $\begin{array}{c}\text { To Dep. } 4 \\
\text { Flow/Unit Cost }\end{array}$ & $\begin{array}{c}\text { To Dep. } 5 \\
\text { Flow/Unit Cost }\end{array}$ & \begin{tabular}{|c|} 
To Dep. 6 \\
Flow/Unit Cost
\end{tabular} & $\begin{array}{c}\text { To Dep. } 7 \\
\text { Flow/Unit Cost }\end{array}$ & \begin{tabular}{|c|} 
To Dep. 8 \\
Flow/Unit Cost
\end{tabular} & $\left|\begin{array}{c}\text { To Dep. } 9 \\
\text { Flow/Unit Cost }\end{array}\right|$ & $\begin{array}{c}\text { Initial Layout in } \\
\text { Cell Locations [e.g. }(3,5),(1,1)-(2,4)\end{array}$ \\
\hline 2 & sapisleme & No & & & & & 35000 & & & & & {$[3,3)-[3,7$} \\
\hline 4 & kimyasalyi & No & & & & & & & 40000 & & & $(6,3) \cdot[8,7$ \\
\hline 5 & pres & No & & & & & & 56000 & & & & {$[9,2)-\{9,5$} \\
\hline 8 & boya & $\mathrm{N}_{0}$ & & & & & & & & & 56000 & $(14,3)-(14,8$ \\
\hline 9 & montaj & No & & & & & & & & & & {$[15,3)-\{15,8$} \\
\hline
\end{tabular}

Şekil 5. K-means algoritması ile oluşturulan kümelere ait koordinatlar ve aylık talep miktarları

\begin{tabular}{|c|c|c|c|c|c|c|c|c|c|c|c|c|}
\hline $\begin{array}{c}\text { Department } \\
\text { Number }\end{array}$ & $\begin{array}{c}\text { Department } \\
\text { Name }\end{array}$ & \begin{tabular}{|c} 
Location \\
Fixed
\end{tabular} & $\mid \begin{array}{c}\text { To Dep. } 1 \\
\text { Flow/Unit Cost }\end{array}$ & $\begin{array}{c}\text { To Dep. } 2 \\
\text { Flow/Unit Cost }\end{array}$ & $\mid \begin{array}{c}\text { To Dep. } 3 \\
\text { Flow/Unit Cost }\end{array}$ & $\begin{array}{c}\text { To Dep. } 4 \\
\text { Flow/Unit Cost }\end{array}$ & $\left|\begin{array}{c}\text { To Dep. } 5 \\
\text { Flow/Unit Cost }\end{array}\right|$ & $\left|\begin{array}{c}\text { To Dep. } 6 \\
\text { Flow/Unit Cost }\end{array}\right|$ & $\left|\begin{array}{c}\text { To Dep. } 7 \\
\text { Flow/Unit Cost }\end{array}\right|$ & $\left|\begin{array}{c}\text { To Dep. } 8 \\
\text { Flow/Unit Cost }\end{array}\right|$ & $\left|\begin{array}{c}\text { To Dep. } 9 \\
\text { Flow/Unit Cost }\end{array}\right|$ & \begin{tabular}{|c} 
Initial Layout in \\
Cell Locations [e.g., $(3,5),(1,1)-(2,4)]$
\end{tabular} \\
\hline 1 & $\mathrm{cnc}$ & $\mathrm{No}_{0}$ & & & 56000 & & & & & & & $(1,3)-(2,7)$ \\
\hline 2 & boykesme & No & 56000 & & & & & & & & & $(3,3)-(4,6)$ \\
\hline 3 & sapisleme & No & & & & 35000 & & & & & & $(5,3)-(5,7)$ \\
\hline 4 & pres & No & & & & & 56000 & & & & & $(6,2)-(6,5)$ \\
\hline 5 & polisaj & No & & & & & & 30000 & & & & {$[6,6)-(6,9)$} \\
\hline 6 & kimyasalyi & No & & & & & & & 40000 & & & $(7,3) \cdot(9,7)$ \\
\hline 7 & eloksal & Yes & & & & & & & & 56000 & & $(10,2)-(13,9)$ \\
\hline 8 & boya & No & & & & & & & & & 56000 & $(14,3)-(14,8)$ \\
\hline 9 & montaj & No & & & & & & & & & & $(15,3)-(15,8)$ \\
\hline
\end{tabular}

Şekil 6. Genetik algoritma ile oluşturulan kümelere ait koordinatlar ve aylık talep miktarları

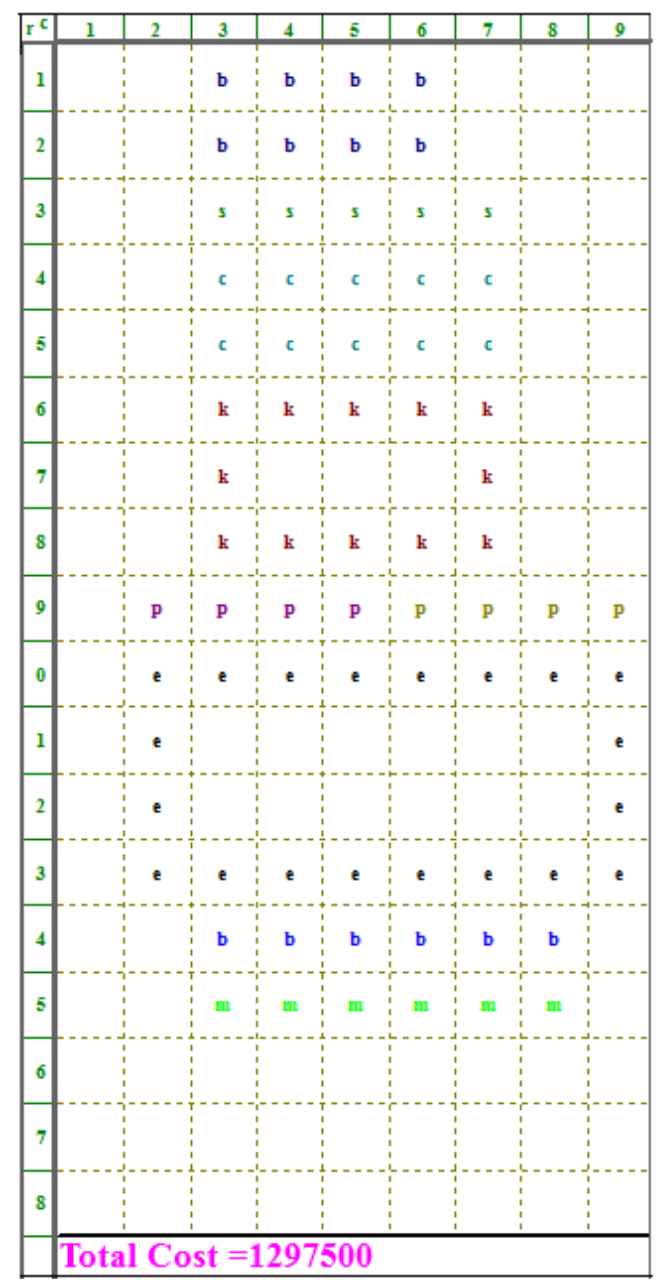

K-Means algoritması ile elde edilen yerleşim

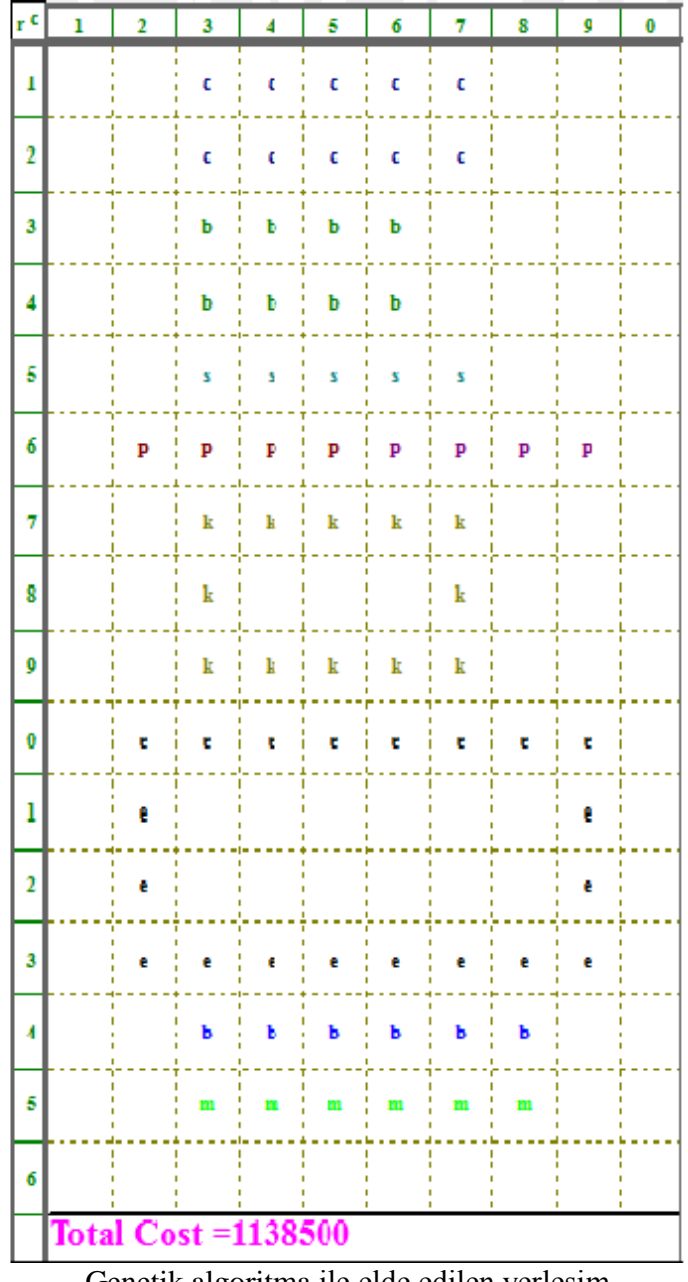

Genetik algoritma ile elde edilen yerleşim

c:CNC, b:Boy Kesme, s:Sap İşleme, k: Kimyasal Yüzey İşleme, e: Eloksal, p: Pres, p: Polisaj, b: Boya, m: Montaj

Şekil 7. K-means algoritması ve genetik algoritma sonucunda oluşan kümelere ait taşıma maliyeti 


\section{Sonuc}

İşletmeler hangi tip üretime sahip olurlarsa olsunlar üretimdeki gerek zaman gerekse maliyet kayıplarını azaltmak için çeşitli yöntemler kullanmaktadırlar. Bu kayıpları azaltmanın etkin yöntemlerinden biride grup teknolojisi ve bunun imalattaki uygulama şekli olan hücresel imalat sistemleridir [18]. Ayrıca işletmelerde makinelerin yerleşiminin hücresel oluşu rekabet güçlerinde de önemli bir etkiye sahiptir [19].

$\mathrm{Bu}$ çalışmanın amacı, alüminyum ve paslanmaz çelikten 200 çeşit profil, aksesuar ve komponent üretimi gerçekleştiren bir imalat işletmesindeki atölye tipi yerleşimi hücresel yapıya dönüştürmektir. $\mathrm{Bu}$ amaç doğrultusunda üretilmekte olan ürünler kmeans algoritması ve genetik algoritma kullanılarak kümelere ayrılmıştır. Daha sonra oluşturulan bu hücrelere göre işletmenin yerleşimi düzenlenmiş ve toplam taşıma maliyetleri hesaplanmıştır. Toplam taşıma maliyetleri incelendiğinde mevcut sistemin toplam taşıma maliyetinin 1.664 .500 br, k-means algoritması ile oluşturulan hücresel sistemin toplam taşıma maliyetinin 1.297 .500 br ve genetik algoritma ile oluşturulan hücresel sistemin toplam taşıma maliyetinin 1.138 .500 br olduğu görülmektedir. Görüldüğü gibi mevcut sistem yerine k-means algoritması ile yeni hücreler oluşturulduğunda toplam taşıma maliyetinde \%22,04'lük, genetik algoritma ile yeni hücreler oluşturulduğunda ise toplam taşıma maliyetinde \%31,60'lık bir azalma sağlanmıştır. Bu nedenle önerilen yerleşim düzeni genetik algoritma ile oluşturulan hücresel sistem olarak belirlenmiştir.

\section{Referanslar}

[1] Y. Ülker ve B. Başaran, "Bir grup teknolojisi modeli olarak hücresel imalat sistemi ve faaliyet tabanlı maliyetleme sistemiyle bütünleştirilmesi", Muhasebe ve Finansman Dergisi, Sayı: 37, s.152$163,2008$.

[2] M. B. Durmuşoğlu, O. Kulak ve H. H. Balcı, "Türkiye'de Hücresel Üretim Uygulamalarının Analizi Ve Değerlendirilmesi”, Endüstri Mühendisliği Dergisi, cilt: 14, say1: 2, s. 2-20, 2003. [3] R. G. Askin and M. Zhou, "Formation of Independent Flow-Line Cells Based on Operation Requirement and Machine Capabilities", IIE Transactions, vol. 30, pp. 319-329, 1998.

[4] S. Ercan, H. R. Yazgan ve S. H. Gökler, "Bir İmalat İşletmesinde Geleneksel Üretimden Hücresel Üretim Sistemine Geçiş: Bir Uygulama", 13. Üretim Araştırmaları Sempozyumu, 25-27 Eylül, Sakarya, (2013).
[5] A. Erişen, "Hücresel İmalat Sistemlerinin Genetik Algoritmalar ile Tasarlanması ve Bir Uygulama", Yüksek Lisans Tezi, İstanbul Üniversitesi, İstanbul, 2011.

[6] M. Lorr, Cluster Analysis for Social Scientist, Jossey-Bass, San Francisco, 1993.

[7] Jr. Hair, R. E. Anderson, R. L. Tatham and W. C. Black, Multivariate Data Analysis, Prentice-Hall, Upper Saddle River, New Jersey, 1998.

[8] Ş. Kalaycı, SPSS Uygulamalı Çok Değişkenli İstatistik Teknikleri, 4. Baskı, Asil Yayın Dağıtım, 2009.

[9] J. B. MacQueen, "Some Methods for Classification and Analysis of Multivariate Observations", Proc. Symp. Math. Statist. and Probability (5th), 281-297, (1967).

[10] P. N. Tan, M. Steinbach and V. Kumar, Introduction to Data Mining, Addison Wesley, 2016. [11] L. Kaufman and P. J. Rousseeuw, Clustering by Means of Means, Statistical Data Analysis Based on The L1-Norm and Related Methods, edited by Y. Dodge, North-Holland, s. 405-416, 1987.

[12] L. Kaufman and P. J. Rousseeuw, Finding Groups in Data: An Introduction to Cluster Analysis, John Wiley and Sons, 1990.

[13] D. E. Goldberg, Genetic Algorithms in Search, Optimization and Machine Learning, AddisonWesley Publishing Company, Reading, Massachusetts, 1989.

[14] C. R. Reeves, Modern Heuristic Techniques for Combinatorial Problems, McGraw-Hill Book Company Inc., Europe, 1995.

[15] X. Wu, C. Chu, Y. Wang and W. Yan, "A Genetic Algorithm For Cellular Manufacturing Design And Layout", European Journal Of Operations Research, vol. 181, pp. 156-167, 2007.

[16] M. A. Panduro, A. L. Mendez, G. Romero and R. F. Dominguez, "Design of Non-uniform Circular Phased Arrays using Genetic Algorithms to Reduce the Maximum Side Lobe During Scanning", IEEE Vehicular Technology Conference, 2696 - 2700, (2006)

[17] B. Özen B. ve E. Afacan, "Dairesel Anten Dizilerinin Genetik Algoritma ile Tasarımı", Elektrik - Elektronik - Bilgisayar ve Biyomedikal Mühendisliği Sempozyumu, Bursa, (2014).

[18] A. Atamtürk, "Hücresel imalat sisteminde hücre ve yerleşim düzeni tasarımı”, Yüksek Lisans Tezi, İstanbul Üniversitesi, İstanbul, 2009.

[19] K. G. Güçlü, "Türk Traktör Fabrikasında Makine Yerleşiminde Hücresel İmalat Uygulaması", Yüksek Lisans Tezi, Gazi Üniversitesi, Ankara, 2006. 